\title{
Refugee migrants as agents of change: Strategies for improved livelihoods and self-reliance
}

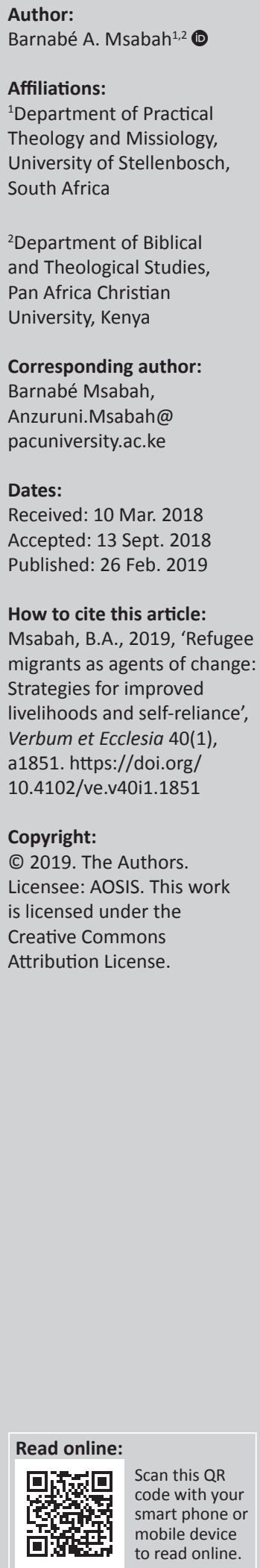

Although many refugees leave their home countries with a certain level of uncertainty concerning their survival in the host country, they are hopeful of improving their livelihood and thus being self-reliant. They seize available opportunities in order to start a new life. In doing so, refugees move beyond solely depending on charity actions, having devised survival mechanisms in their new setting by means of self-reliant strategies. This article, therefore, looks at the refugee migrants as agents of change in view of the self-reliance strategies they use for survival. Furthermore, the article points to the courage of the refugees in the host country by presenting qualitative evidence on how refugees' livelihood strategies have contributed to the improvement of their own well-being in general and, in particular, that of some locals. The data for this study were gathered using in-depth interviews with refugees living in Cape Town, South Africa.

Intradisciplinary and/or interdisciplinary implications: This paper is transdisciplinary in that it presents an ecclesial response to the global challenges facing the refugee community. This is because it aims at transforming the painful experiences of the refugees into opportunities for improved livelihoods and holistic well-being. The paper further depicts how practical theology informs understandings of the phenomenological techniques in an attempt to explore the rhythms of social life from the perspective of the issue under investigation. The article is, therefore, a theological underpinning that informs development practitioners and practical theologians on how to efficiently respond to the pressing needs of refugees using hope as an available resource. In this manner, the article presents strategies that would assist policymakers in devising sustainable policies and programmes that aim at improving refugees' livelihoods.

\section{Introduction}

In most African countries, the refugee phenomenon is often bred by serious violations of human rights and by conflicts or various other forms of violence (Msabah 2016, 2018a). Ferris' (1993:68) claim that 'from time immemorial, people have always sought to move when they were unable to survive' is testimony to the fact that migration has been happening long since and explains why Harzig, Hoerder and Gabaccia (2009:8) argue that 'the history of humanity is a history of migration'. Refugees seek to improve their lives, and as they cannot count on continued relief and hand-outs, they try to be self-reliant. They flee conflicts, violations of human rights and economic deprivation, which is why they often show courage and ingenuity in their efforts to survive in host countries. Ferris (1993:66) further points out that people leave their countries because they are either 'unable to survive or afraid to live there'. Her sentiments indicate that, for some people, home might be the most dangerous place to live, and asylum could be the only alternative (see also Msabah 2016, 2018b). For the above reasons, refugees strive for local integration regardless of what they endure. Some of them rely on short-term humanitarian aid because of restrictive policies of the host country that limit them from exploring other avenues. However, in South Africa, for example, refugees enjoy freedom of movement and are entitled to various legal rights, yet they often feel vulnerable - and this results in compromised well-being and exposed dignity (Amit, Vigneswaran, Monson \& Wachira 2009; Belvedere 2007:59; Buscher 2011:21; Sutton, Vigneswaran \& Wels 2011:31). They are often considered parasites that deprive the locals from accessing various services with ease and enjoying the fruit of their struggle for freedom. Furthermore, they are often seen by a certain segment of the local population as people who exhaust the country's resources and who 'should not be in South Africa in the first place' (cf. Belvedere 2007:58). Such sentiments cause refugees to live in renewed fear of xenophobic attacks, but at the same time prompt them to develop self-reliant strategies in order to survive in such an intolerant environment. 


\section{Ordinary people with extraordinary challenges}

The recent research conducted by Msabah (2016) argues that refugees are ordinary people facing extraordinary challenges. Yet, even in the face of such challenges, refugees are known to be courageous with a strong desire to rise above the hurdles in their day-to-day lives in an attempt to improve their livelihood (see also Amit et al. 2009; Beek 2000; Swindal 2001). Here, the term livelihood is used to refer to human activities that enable people to sustain themselves by meeting their basic needs. By carrying out these livelihood activities, people acquire the knowledge, skills, social relationships, raw materials and other resources needed to meet their individual or collective needs in a sustainable and dignified manner. In this way, refugees strive to thrive in spite of the challenges they face. Nevertheless, it could be argued that the South African Department of Home Affairs (DHA) adds to the refugees' vulnerability because of the many irregularities related to application and issuance of documents (see Msabah 2016). This is because most asylum applications are rejected by the Refugee Status Determination Officer (RSDO) over the claim that the applicant had not left their home country because of persecution. Most asylum seekers are accused to have come to South Africa in the quest for a better life, instead, and therefore do not deserve asylum in the country.

In this regard, an annual report by the DHA (covering the period between 01 April 2012 and 31 March 2013) indicates that a total of 78142 applications for asylum were received, of which 36657 were rejected on the basis that they were 'manifestly unfounded, abusive or fraudulent' and a further 24520 were deemed 'unfounded' and rejected on that basis; only 3908 claims were approved and applicants granted asylum (see DHA 2013b:90). Statistically, this implies that only one out of every 20 applications received was approved in 2012. It points to the claim of this respondent from Burundi who said that 'living in South Africa is difficult because the local population don't like foreigners' (cf. Msabah \& BowersDu Toit 2017). One can therefore postulate that such rejections not only increase cases of undocumented migrants in the country but also enhance the likelihood of corruption, as fear of rejection may prompt the refugees to bribe the officials to obtain the document and thereby avoid arrest, detention and deportation.

Various studies carried out in this domain (see Amit 2013:3233; Kane \& Kane 2013:36; Kiama \& Likule 2013:34-35; Msabah \& Bowers-Du Toit 2017) indicate that arresting and detaining refugees on the basis of documentation legitimise a variety of unlawful practices and give rise to increased opportunities for bribery. Msabah (2016), in his research on the health and well-being of refugee migrants, finds that proper documentation is essential for refugees to settle and pursue improved livelihoods within the requirements of the law. A 37-year-old man from Burundi who works as a barber in Bellville had this to say regarding the A4-sized permit given to refugees, which is often refused by most employers who require a green (i.e. South African) I.D.:
[The question of documentation] affects me negatively. Because with the A4 size temporary permit no job; even with the Status and I.D.; no professional job. That is why I do not do my professional job. (Burundian refugee, 37 years old, male)

In the same vein, Msabah's (2016) research indicates that a 42-year-old respondent from Ethiopia who vends merchandise in Mowbray had this to say on the issue of documentation and its consequential likelihood for corruption, 'it takes very long to get it and there is [sic] people they take the shortcut to get it. I think that make it bad for the others'. As indicated by this respondent, the research further points out that some refugees decide to use the 'shortcut' to acquire their documents to make a living and improve their livelihoods through legal means. It is noteworthy that the 'shortcut' he is referring to is monetary. These sentiments become more and more apparent as another respondent who had been living in South Africa for more than 10 years says, 'I have been trying to get an I.D. book since 2005 but they never responded without any reason'. Reflecting the increased resentment with regard to the question of documentation and service delivery by the DHA, a middle-aged Rwandan man said:

The Home Affairs is the most horror place I never see; to go to Home Affairs and to stay illegal is just the same; we need international community to take care of us; not Home Affairs. (Rwandan refugee, 35 years old, male)

These voices indicate that great courage is required to remain legally documented in South Africa because, it seems, the DHA is not making it any easier for refugees to access essential services for their stay. The challenges of documentation also mean that refugees depend on humanitarian assistance for survival rather than pursuing alternate means of livelihoods. It could be argued that such documentation challenges not only deprive refugees of their right to asylum and development but also contribute to an increase in criminal activities, in which some refugees engage for survival. Refugees benefit from humanitarian assistance mostly when they are still new in the country. This is because assistance is often reserved for the most vulnerable, the marginalised and the unaccompanied or orphaned children (cf. Msabah \& Bowers-Du Toit 2017). Despite the restrictions imposed on refugees, they find many ways to survive and make a living, including performing daily tasks for the informal sector. Lack of access to the labour market can increase the risk of harmful coping strategies such as survival prostitution, child labour and early or forced marriage (see Msabah 2016, 2017; Msabah \& Bowers-Du Toit 2017).

In view of this, as South Africa seems paralysed by the challenges posed by migratory pressure at its borders, it is time to stop considering refugees in South Africa as victims or problems, and to understand that they can become (or are already) agents of change, from whom will come the solutions that the local community seeks. In South Africa, data from research show that some refugees support one another socially and redefine the approach to the migration issue (Msabah 2016, 2017, 2018a, 2018b; Msabah \& Bowers-Du 
Toit 2017). Far from the idea of being a 'burden' or creating a 'crisis', they transform the current situations they face into opportunity: that of enriching themselves with knowledge and skills to help other new refugee seekers who cross the borders to flee war or poverty (Rosenkranz 2013). As a result, some humanitarian organisations no longer consider refugees to be recipients of aid but empower them to become active agents of change and their own integration because that is what refugees, in reality, are.

Of course, the security challenges of such large-scale population movements, and the fact that many refugees desperately need help and care, must not be taken lightly. But when hundreds of thousands of people flock to your borders, these are not short-term challenges because many of them may not be in a position to return to their respective countries of origin. Based on previous waves of migration to and through South Africa, it is possible that a large proportion of them will remain in the country all their lives (Msabah 2017, 2018a, 2018b). Their children and grandchildren will be born in South Africa and will grow up in South Africa. Treating them as objects of charity or threats would be the worst way to begin the long-term process of integrating them into the social, political and economic milieu in South Africa. Very quickly, fears that refugees live on the margins of society and depend on government support would become reality (cf. Msabah 2016, 2017, 2018a, 2018b; Msabah \& Bowers-Du Toit 2017).

\section{Refugees' resolve for improved well-being}

As can be deduced from the preceding discussion, humanitarian assistance is a short-term strategy that allows refugees to rebuild their lives in the host country. Refugees themselves seem to indicate that instead of receiving food to survive, they desire to be exposed to initiatives that will allow them to take their destiny into their own hands, in the interest of the host countries. As such, many refugees use the assistance they receive while they are still 'newcomers' both to establish themselves and rebuild their shattered lives and thereby become self-reliant. They strive to thrive albeit sheer vulnerability. According to the UNHCR (2011:15), selfreliance is the social and economic ability of an individual, household or community to meet basic needs in a sustainable manner and with dignity' (see also Msabah 2016). Therefore, being self-reliant improves and strengthens refugees' livelihoods, on the one hand, and reduces their vulnerability and dependence on humanitarian assistance, on the other. In their quest for improved livelihoods, refugee migrants accept to work for insufficient payment, as they strive to find employment that might secure them enough money for their continued existence (Msabah 2017). This indicates that quality livelihoods are essential for the emotional and socioeconomic well-being of refugee migrants, which explains why the protection of refugees is concomitant to ensuring their livelihoods.

All the refugee women interviewed in this research are tenants (see Msabah \& Bowers-Du Toit 2017). Many of them are widows, their husbands having been killed in their home countries. After they arrived in South Africa, they were hosted either by their fellow countrymen or benefactors, and they all ended up becoming tenants. This phenomenon finds its explanation in the discomfort and overhead expenses that they create among the host families. Here is the testimony of Zaina, a Congolese hairdresser:

When I arrived in Cape Town in 2009, I was accommodated by a countryman I met by chance in the street. We were five; my 4 children and I shared a room with another family of four. This way of life forced us to look for another room after two weeks. (Congolese refugee, 28 years old, female)

Strengths refugees have on arrival (e.g. skills, resources and their physical health) are essential to increase their access to safe and productive jobs. However, these assets are often insufficient from the beginning or weaken with the passing years of displacement. Studies carried out by various researchers (see Buscher 2011:26; Harrell-Bond 2002; Jacobsen 2012:585; Msabah 2016; Potts 2011) indicate that the circumstances in which refugees engage in activities aimed at improving their own livelihoods are not supported by the relevant authorities despite the refugees contributing to the socio-economic growth of the country in the form of skills and needed labour. This might be attributed to the rules and regulations in most host nations that restrain the refugees. Msabah (2016, 2017) indicates that in South Africa, for example, until recently, it was illegal for asylum seekers to study, work or own businesses, and it is still illegal for both asylum seekers and refugees to own property or to access financial services such as loans. Msabah (2016) reports on the findings of his research citing a university student from the Democratic Republic of the Congo (DRC) who says:

As a refugee I don't exercise all my rights; there are rights that a refugee cannot claim because he is not a citizen of the country; but a refugee student, for instance, should be allowed to apply for a loan to finance his studies. (p. 273)

Msabah (2016, 2018a; see also Msabah \& Bowers-Du Toit 2017) further points out that, in South Africa, refugees are now allowed to study and work, although finding work is still a challenge. This is because the refugees find themselves competing for jobs with local citizens who are always prioritised (see Amit 2013; Belvedere 2007). This renders their buoyant spirit easily broken and their quest for improved well-being a challenge. A 33-year-old refugee from Burundi who believes he has 'unused talent' said the following:

I have been in South Africa for 12 years and in exile for 18 years. [I] have managed to get BSc, PGCE but have no teaching position because of the document I am using. Yes the country needs science teachers but fails to give a teaching post no matter how I managed to work on short contract for some months. I hold unused talent that the countries, the world needs to profit from. (Burundian refugee, 33 years old, male)

These sentiments highlight the government's policy of prioritising the local population for civic services. The 'unused talent' of the respondent, however, could be an asset to the welfare and development of the country. As it were, 
a common misconception is that refugees are a dependent people surviving at the mercy of either the humanitarian organisations or the generosity of the local community (Msabah 2016, 2017, 2018b). In contrast, the study has revealed that refugees exploit various available avenues in an attempt to improve their well-being and enhance their livelihoods. Msabah (2016) found that refugees improve their livelihoods and build resilience through what he calls 'internal factors', 'external factors' and 'supernal factors'. Here, he notes that internal factors involve personal qualities such as courage, strength of mind, determination and skills, while external factors are qualities that involve the support refugees receive from friends, relatives, faith communities and humanitarian organisations. Finally, Msabah (2016) argues that refugees draw strength from supernal factors such as religious beliefs and spirituality (see also Hutchinson \& Dorsett 2012:59-63). It could be argued, therefore, that all of these factors interact to help refugees improve their quality of life.

Most refugees are economically active and productive in their own way. The majority of refugees were found to be 'working', although most of them are self-employed in the informal sector (see Msabah 2017, 2018a, 2018b; Msabah \& Bowers-Du Toit 2017). Those from the Great Lakes region were generally in the security line of work, car-guarding, repairing of appliances, hairdressing and barbing. Those from the Horn of Africa mostly owned or worked in retail stores or supermarkets (Msabah 2016, 2017). Furthermore, the study found that most refugees in Cape Town have relatively strong societies, which increase their trust as well as their ability to work together and help each other. Such societies are social capital that multiplies their connections and gives them access to financial capital. They use social media to obtain support from relatives or friends. The same applies when they want to send remittances to their home countries. There are many refugeeowned financial services in the city of Cape Town that facilitate money transfers abroad. These services provide an alternative to the South African banking system whose policies vis-à-vis refugees are very restrictive (Msabah 2016).

In some cases, refugees make contributions to assist those in need, especially during bereavement or any other tragedy (see Msabah \& Bowers-Du Toit 2017). This explains why refugees were also found to demonstrate enviable solidarity with the newcomers in their midst whom they accommodate from the time they arrive until they find a way to earn a living. Those who own businesses, such as the Somalis, introduce the newcomers to the world of business without delay. One respondent asserted the following:

If South Africa was a good country it suppose [sic] to assist refugees fully because we are paying tax and create job; imagine if you come to Bellville many shops of foreigner they employ many South Africans. And imagine apartheid time South African was refugee in all over Africa but they treat them nice until 1994. [sic] (Somali refugee, 36 years old, male)

Msabah (2016) argues that the words of this respondent point to the fact that refugees are economically industrious and have acquired skills that would render them useful to the host community, if allowed to fully explore their potential. As it were, it cannot be overemphasised that the improved livelihoods of migrants are linked to the acquisition of goods, services and money. Unlike other migrants, however, refugees find little opportunity to increase their means of support or sources of revenue. They face realities that thwart their holistic well-being and prevent them from exploring various development avenues for self-reliance and empowerment.

It can be argued that without tangible efforts and a strong determination to create a better, inclusive society, the lives of those who are pushed to the margins of society could well be endangered (see Msabah 2016, 2017; Msabah \& Bowers-Du Toit 2017). This is why the most vulnerable in society need empowering hope as a resource for self-reliance if they are to improve their livelihoods. Empowerment by hope could revitalise their desires and propel them to find meaning in life despite the unfortunate circumstances they find themselves in. This explains Moltmann's (1967:59) statement that, '[a] hope which is not the hope of the oppressed today is no hope for which [one] could give a theological account' (see also Brueggemann 2001; Fyodorov 2003). In view of this, it can be said that refugees' resolve to succeed is also demonstrated by their mental strength, while their hope for improved livelihoods and holistic well-being impels them to work even harder to establish their presence in mainstream society and find space in the host community. The hope of seeing their dignity restored, therefore, is made concrete in the pursuit of and access to opportunities that could improve their livelihoods. In this regard, Msabah (2016, 2017, 2018a, $2018 b)$ argues that refugees end up being their own bosses because finding a job is a challenge even to the local population, which is why, even when salaried employment is not forthcoming, their financial burdens compel them to engage in some form of self-employment to preserve their dignity and economic independence.

Faced with these challenges, some Congolese refugees have launched the Vision for the Development of Fizi (VIDEFI) organisation, which mobilises African communities living in South Africa (around the Bellville areas) as refugees to help them find work or investors for their business projects, and give them advice to adapt to an unknown culture. They have also set up a network of refugees who have become successful entrepreneurs to inspire and support those who wish to create their own small enterprises (Msabah 2017, 2018a, 2018b). It is in this vein that Fatuma, a refugee woman from Eritrea, encourages the creativity of refugees and local communities as she mobilises volunteers to teach refugees isiXhosa, one of the local languages. This is empowerment. It is about developing tools capable of transforming a group, often considered powerless, hopeless and as an object of pity or disdain, into agents of change who control their own destiny. If South Africa could come closer to this state of mind, the country could become more than just a shelter - a place of opportunity and creativity where refugees find meaning and fulfilment (see Msabah \& Bowers-Du Toit 2017). 


\section{Refugees' strategies for building resilience}

\section{Putting hope into action}

The church is called upon to be a catalyst of transformational development by being not only reactive but also proactive in the face of the pressing needs of those whose hope is being diminished, those threatened by systemic poverty, those dehumanised by the established structures, those pushed to the margin of mainstream society and so on (see Msabah 2016, 2017; Msabah \& Bowers-Du Toit 2017). According to Bowers-Du Toit $(2015: 523,524)$, responding to the needs of such people is not merely an act of goodwill or charity but a social justice issue. In the same vein, the refugee phenomenon is characterised by poverty and marginalisation even as refugees themselves are often pushed to the very margin of mainstream society. In this scenario, as the church acts in response to the socio-economic needs of those in need, it does so to correct the prevailing unjust structures that relegate refugees to a state of nobodiness. It should be noted that the refugee phenomenon fosters social cohesion in the host country, while refugees themselves contribute to the needed social change in the country of origin, and vice versa. This explains a kind of dualism in their being and belonging. Such dual membership of refugees and their descendants gives them the capacity to be in solidarity with both those in their host nation and those in their country of origin. This competence, which is undervalued albeit being undoubtedly an added value, tends to be called into question by certain states that see it as a source of the weakening of their sovereignty and of their national system of values.

In this regard, Msabah's (2016) study reveals that most refugees in Cape Town do not want to return to their respective home countries as yet regardless of the bad treatments they endure on a regular basis in South Africa, their host country. This could be because of the lifethreatening situations back home or because the hope of having an improved livelihood and holistic well-being is greater in South Africa than compared with their home countries. This explains why refugees put their hope into action to achieve what they aspire for. Msabah (2016, 2017) further argues that despite the many challenges and the bad experiences that refugees have with individuals and institutions, most of them are reasonably better off in the different facets of their lives than they ever were in their home countries. It could be argued, in this regard, that refugees' holistic well-being and improved livelihoods rest on the actuation of their simmering hope, which is not 'a kite at the mercy of the changing winds' (cf. Tasker 1962:535; see also Msabah \& Bowers-Du Toit 2017) but 'an anchor for the soul, firm and secure' (cf. Heb 6:19). As such, one may deduce that refugees' hope for improved livelihoods and holistic well-being is not easily shaken by the 'changing winds' or the pressing realities of this world.

It is in this regard that Brueggemann (2002:102) argues that 'hope is a distinctive mark of faith with dangerous and revolutionary social potential' (see also Msabah 2016, 2018a, 2018b; Msabah \& Bowers-Du Toit 2017). With this, Brueggemann suggests that hope and faith correlate. In this regard, refugees put hope into practice as a survival strategy within the perimeters of faith. This is why the church should make known and defend the relevance of hope because of 'the common human experience of suffering and the dangers [of hopelessness] that it brings forth' (Hryniewicz 2007:68; see also Msabah 2016, 2017). This is because hope is experienced from within and reaches the depths of human soul and is therefore as necessary as light and air to human life (see Bielawski 2007:284; Msabah 2016, 2017; Tinder 1999:13). It could be said, therefore, that it is the existence of hope rather than the lack of it that keeps refugees going notwithstanding the amplified helplessness and undignified treatment they often face.

Most refugees capitulate to despondency for the reason that the current system is quite wanting. Nevertheless, the church may neither follow the patterns of the system nor pull itself out of it. It is called to arise and stand up so as to provide the said system with a transforming framework that would enable the status quo to change in an attempt to invite the social fabric to live in a new way - the way of faith, love and hope (Msabah 2016, 2018b; see also Tasker 1962:536). In this regard, the church helps the dispositions, the longings and the imaginings of the despondent to be rooted afresh in faith, love and hope. This is why Moltmann (1971:49) argues that the more faith is in harmony with the groaning of people, the more love is in solidarity with them, and the more comprehensive the horizon of hope becomes. Here, the groaning people in Moltmann's observation consist also of refugees whose hope is usually thwarted by the many circumstances related to their being and belonging.

The majority of refugees leave their countries uncertain of their survival in South Africa, but they continue to put their hope into action to pursue and improve their livelihoods (see Carbonnier 2012; Roux 2009). To nurse the frustrations and disappointments of the day, they grasp each presented occasion to shape their destiny by building new hope. In doing so, they refuse to depend on charity and hand-outs and engage in various activities, however small, for their selfempowerment. For them, putting into practice is not an abstract notion because it is made possible through their active engagements and participatory actions.

\section{Waiting patiently}

Waiting is associated with the virtue of patience. The word 'patience' suggests bearing a heavy load from the oppressor and abiding under such difficult circumstances when it is not possible to escape (see Msabah 2016, 2017; Strong 2009:5281). It is therefore associated with long suffering, which is actually the term used for patience in the authorised version of the Bible (see Brown \& Falkenroth 1976:766). In Msabah's (2016) research, a respondent from the DRC explained his waiting situation in this way: 'myself my asylum application have [sic] been rejected in 2006 then I did appeal 2008. Now I 
am still waiting final result till now'. Here, it appears that waiting patiently is not easy because it results in a sort of 'waiting for Godot' (Anders 1965; Beckett 1965; see also Msabah, 2016, 2018b). Although the waiting for this respondent's new identity took longer than expected, the respondent kept on waiting. This is an indication that for refugees, waiting is a hopeful endurance and, therefore, a survival strategy to improve their own livelihoods. Indeed, as Sutton et al. $(2011: 31,36)$ found, 'it is hope that makes the powerless persevere and (...) ultimately makes waiting a phenomenon that is socially productive'. In the same vein, using Bourdeau's (2013) analogy, it could be said that hope transforms refugees' waiting into a socially productive and resourceful weapon that generates enough strength and breeds ability to wait patiently in spite of the fact that the prevailing circumstances do not give any reason to do so or even though there are no rational grounds for it. In this scenario, refugees wait in active hope as a strategy to pursue improved livelihoods for their own survival (Msabah 2016; Msabah \& Bowers-Du Toit 2017).

This explains why Keshgegian (2006:188) argues that 'we learn to hope anew when we practice hope'. It is indeed the case that refugees have a strong desire to be productive to take care of their families and pay the bills related to their livelihoods. They could be said to put their hope into practice to attain the hoped-for. Putting hope into action is what makes refugees stronger - turning their long wait into a productive manifestation. This indicates that waiting is a hopeful experience coupled with activity, rather than passivity, as one awaits the hoped-for. This is why the hope for peace and justice for refugees must encourage us to work for peace and justice now, while the hope for a better society must be translated into concrete actions now because this is what would pave the way for the realisation of what we hope for. In this regard, Botman (2001:70) notes that when one translates hope into action, they engage in 'a theological grounding to become meaningful' in this 21st century generation (see also Msabah 2016). Thus, the practice of hope is essential to human living. This is why the predominance of despair ought to provoke the church to become involved in whatever is of public concern to bring about renewed hope.

\section{Ethical considerations}

Because research involves obtaining information from people and about people, it is possible to exploit those being researched. Hence, there was a need for ethical considerations to protect and respect the feelings and rights of the researched, that is, those participating in research as subjects. For that reason, we began the fieldwork after obtaining ethical clearance from the Research Ethics Committee (REC). By giving the clearance, the REC allowed the fieldwork to take place because there was a guarantee to protect the identity and dignity of the potential participants. The entire process of this research from planning to execution was conducted in an ethical manner. I provided participants with an informed consent form to approve their participation in view of the sensitivity of the phenomenon under study. However, I was also conscious to remain alert for situations where a participant may decide to withdraw consent. Thus, the research adheres to internationally recognised ethical principles of confidentiality and respect for human dignity. I adapted all the ethical principles of human research in line with human dignity to the local contexts to obviate related misunderstandings and avert any possible damages to the participant during the process of this research practice. In addition, an application for ethical clearance to secure consent to conduct the study was made beforehand. The clearance protects both the researcher and the participants.

\section{Summary of findings and conclusion}

Refugees in South Africa face several challenges, including the fact that they are often considered subhumans by a certain section of the local population (Msabah 2016, 2017, 2018a; Msabah \& Bowers-Du Toit 2017). Their situation requires that the international community redouble efforts to attain sustainable solutions. As the number of forced migrants continues to grow, more efforts need to be made to address the root causes of forced migration and to prevent new situations from becoming protracted situations. It should be noted that refugees migrate mostly because they do not lead a life of dignity and self-worth in their home countries (see Msabah \& Bowers-Du Toit 2017). Thus, their emigration is a quest for freedom and dignity, without which one is reduced to nothingness.

This paper has highlighted the means of support that refugees utilise to make a living despite the demanding conditions they find themselves in. Based on the research findings, the paper has revealed that (1) although most refugees in South Africa struggle to attain an improved level of livelihood, migration has enhanced their socio-economic savoir-faire, which benefits the welfare and development of the local citizens, (2) the majority of refugees in Cape Town have shifted from short-term survival mechanisms, such as the dependence on relief from charity organisations, to longterm strategies in the pursuit of improved livelihoods and (3) the strategies pursued by refugees for livelihood make them agents of change and proponents of hope in action. The study, therefore, pointed out that most refugees work hard to earn a living and do not prefer humanitarian aid. This marks a radical shift from short-term survival strategies to longterm mechanisms using hope in action as their theory of change.

It has been indicated that refugees are victims of circumstances that have inflicted neediness, hopelessness and misery upon them (Msabah 2016). This explains why they are capable people although momentarily without the requisite resources. Even though they are faced with challenges, refugees put their hope into action to increase their chances of improved livelihoods. Their tenacity to flourish against the odds forces them to engage in all sorts of jobs and money-making activities to make a living. In doing so, they contribute to the growth of the local economy and to their own quality of life. Such tenacity to improve quality of life and holistic 
well-being is a commitment to reach a certain degree of selfreliance, which would see them integrate into the local community.

In this regard, despite the fact that refugees in South Africa are depicted as destitute people whose source of revenue depends on the benevolence of others, this study reveals that refugees are agents of change and contribute to the socioeconomic growth of the country. They have demonstrated the ability to use a number of coping strategies to ensure their improved livelihoods and holistic well-being. They do this not only for survival but also for the purpose of giving their life a new meaning through dignified and sustainable means of support (Msabah 2016).

In spite of the challenges refugees face on a daily basis, their narratives express hope of a better tomorrow, which was presented in this article as a practical paradigm for human development. In other words, actuating hope is necessary for social transformation as seen through the lives of refugees. When hope is put into action, it could rekindle the ambitions of the less privileged in the community. The livelihood strategies used by refugees constitute a coping mechanism and an opportunity for new hope as they strive to go beyond the satisfaction of basic needs for survival to the meeting of specific goals for sustenance. As Msabah (2016) finds, the refugee phenomenon presents an opportunity that might be exploited if we are to bring about the desired transformation leading to a more productive economy.

As seen through the lives of refugees in Cape Town, to be human should entail being discontented with the everpresent predicaments of life that are increasingly causing despair in the world. It should further entail helping those in despair to hope anew. It is this discontentment that moves hope towards action. Our attitude towards development should therefore be reflected in the efforts to empower the powerless for self-reliance and restore their dignity.

\section{Acknowledgements}

The author would like to thank the Department of Practical Theology and Missiology, Faculty of Theology, University of Stellenbosch for the support and the Department of Biblical and Theological Studies, School of Theology, Pan Africa Christian University for providing infrastructural resources and working time to write this article.

\section{Competing interests}

The author declares that he has no financial or personal relationships that may have inappropriately influenced him in writing this article.

\section{Funding information}

This project was funded by the Department of Practical Theology and Missiology, Faculty of Theology, University of Stellenbosch.

\section{References}

Amit, R., 2013, 'Security rhetoric and detention in South Africa', in M. Couldrey \& M. Herson (eds.), Forced Migration Review, vol. 44, pp. 32-33.

Amit, R., Vigneswaran, D., Monson, T. \& Wachira, G.M., 2009, National survey of the refugee reception and status determination system in South Africa, Forced Migration Studies Programme, Wits University, Johannesburg.

Anders, G., 1965, 'Being without time: On Beckett's play Waiting for Godot', in M. Esslin (ed.), Samuel Beckett: A collection of critical essays, pp. 140-151, Prentice-Hall, Englewood Cliffs, NJ.

Beckett, S., 1965, Waiting for Godot, 2nd edn., Whitstable Litho, Kent.

Beek, K.A., 2000, 'Spirituality: A development taboo', Development in Practice 10(1), 31-43. https://doi.org/10.1080/09614520052484

Belvedere, M.F., 2007, 'Insiders but outsiders: The struggle for the inclusion of asylum seekers and refugees in South Africa', Refuge 24(1), 57-70.

Bielawski, M., 2007, 'Thinking about church with hope: The example of Waclaw Hryniewicz', in 'W. Hryniewicz, The challenge of our hope, pp. 269-285, RVP, Washington, DC.

Botman, R.H., 2001, 'Hope as the coming reign of God', in W. Brueggemann (ed.), Hope for the world, pp. 69-81, Westminster John Knox Press, London.

Bourdeau, M., 2013, 'Auguste Comte', in E.N. Zalta (ed.), The Stanford Encyclopedia of Philosophy, viewed 18 October 2013, from http://plato.stanford.edu/archives/ win2013/entries/comte/

Bowers-DuToit, N., 2015, “'Rise up and walk”: Tracing the trajectory of the Carnegie discourse and plotting a way forward', NGTT 55(3-4), 511-531.

Brown, C. \& Falkenroth, U., 1976, 'Patience, steadfastness, endurance', in C. Brown (ed.), The new international dictionary of New Testament Theology, pp. 764-765, Paternoster Press, London.

Brueggemann, W., 2001, 'Communities of hope midst engines for despair', in W. Brueggemann (ed.), Hope for the world, pp. 150-157, Westminster John Knox Press, London.

Brueggemann, W., 2002, 'Hope', in W. Brueggemann (ed.), Reverberations of faith: A theological handbook of Old Testament themes, pp. 100-102, Westminster John Knox Press, London.

Buscher, D., 2011, 'New approaches to urban refugee livelihoods', Refuge 28(2), 17-29.

Carbonnier, G., 2012, Religion and development: Reconsidering secularism as the norm, Leiden, Boston, MA.

Department of Home Affairs (DHA), 2013a, Annual report: 2012-2013, Home Affairs, Pretoria.

Department of Home Affairs (DHA), 2013b, Refugee status \& asylum, Home Affairs, viewed 15 October 2013, from http://www.home-affairs.gov.za/index.php/ refugee-status-asylum

Ferris, E.G., 1993, Beyond borders: Refugees, migrants and human rights in the postCold War era, WCC, Geneva.

Fyodorov, N., 2003, 'Philosophy of the common cause', in V. Zenkovskij, History of Russian philosophy, p. 968, Routledge, London.

Harrell-Bond, B.E., 2002, 'Can humanitarian work with refugees be humane?' Human Rights Quarterly 24(1), 51-85. https://doi.org/10.1353/hrq.2002.0011

Harzig, C., Hoerder, D. \& Gabaccia, D., 2009, What is migration history? Polity Press, Cambridge.

Hryniewicz, W., 2007, The challenge of our hope: Christian faith in dialogue, RVP, Washington, DC.

Hutchinson, M. \& Dorsett, P., 2012, 'What does the literature say about resilience in the refugee people? Implications for practice', Journal of Social Inclusion 3(2), $55-78$

Jacobsen, K., 2012, Refugee livelihoods in urban areas: Identifying program opportunities, Feinstein International Center, Tufts University, Boston, MA.

Kane, M.C. \& Kane, S.F., 2013, 'A last resort in cases of wrongful detention and deportation in Africa', Forced Migration Review 44, 36.

Keshgegian, F.A., 2006, Time for hope: Practices for living in today's world, Continuum, London.

Kiama, L. \& Likule, D., 2013, 'Detention in Kenya: Risks for refugees and asylum seekers', Forced Migration Review 44, 34-35.

Moltmann, J., 1967, Theology of hope, SCM Press Ltd., London.

Moltmann, J., 1971, Hope and planning, SCM Press Ltd., London.

Msabah, B.A., 2016, 'Empowerment by hope: A phenomenological study on the health and wellbeing of African refugees', unpublished doctoral dissertation, University of Stellenbosch, Stellenbosch, viewed n.d., from http://scholar.sun. ac.za/handle/10019.1/98666

Msabah, B.A., 2017, 'Situating the global refugee crisis within the context of ecclesial diaconia and praxis: The case of Cape Town, South Africa', in P. Launonen \& M Valtonen (eds.), Diaconia in dialogue - The challenges of diversifying contexts, $\mathrm{pp}$. 166-188, Redi - The International Society for the Research and Study of Diaconia and Christian Social Practice, Helsinki, viewed n.d., from https://www.theseus.fi/ bitstream/handle/10024/136186/DIAK_tyoelama_12_verkko.pdf?sequence=1

Msabah, B.A., 2018a, '“And the greatest of these is hope": Reframing the global refugee crisis', Transformation 35(2), 1-7. https://doi.org/10.1177/0265378818783590

Msabah, B.A., 2018b, 'Horizons in transformational development and transnational migration: Does hope matter?', Scriptura 117(1), 1-14, viewed n.d., from http:// scriptura.journals.ac.za/pub/article/view/1369/1282 
Msabah, B.A. \& Bowers-Du Toit, N., 2017, "'We live, and move, and have our being": Refugees' vulnerability and the ecclesial challenge for diaconal praxis', Diaconia 8(2), 188-200. https://doi.org/10.13109/diac.2017.8.2.188

Potts, D., 2011, 'Making a livelihood in (and beyond) the African city: The experience of Zimbabwe', Africa 81(4), 588-605. https://doi.org/10.1017/S0001972011000489

Rosenkranz, E., 2013, Those people: Political construction of refugees and asylum seekers in South Africa, Lund University, Lund.

Roux, N., 2009, Migration and urbanization: Towards a 10-year review of the population implementation in South Africa (1998-2008), Department of Social Development, Pretoria.

Strong, J., 2009, Strong's exhaustive concordance of the Bible, Hendrickson, Peabody,
Sutton, R., Vigneswaran, D. \& Wels, H., 2011, 'Waiting in liminal space: Migrants' queuing for home affairs in South Africa', Anthropology in South Africa 34(1\&2) 30-37. https://doi.org/10.1080/23323256.2011.11500006

Swindal, J., 2001, Faith and reason, Internet Encyclopedia of Philosophy, viewed 17 October 2013, from http://www.iep.utm.edu/faith-re/

Tasker, R.V., 1962, 'Hope', in J.D. Douglas (ed.), The new Bible dictionary, pp. 535-536, Inter-Varsity Press, London.

Tinder, G., 1999, The fabric of hope: An essay, Emory University, Atlanta.

UNHCR, 2011, Promoting livelihoods and self-reliance: Operational guidance on refugee protection and solutions in urban areas, UNHCR, Geneva, Switzerland.

UNHCR, 2012, Livelihood programming in UNHCR: Operational guidelines, UNHCR, Geneva, Switzerland. 